The Economics of E-commerce 



\section{The Economics of E-commerce}

A Strategic Guide to Understanding and

Designing the Online Marketplace

Nir Vulkan

Princeton University Press

Princeton and Oxford 
Copyright (c) 2003 by Princeton University Press

Published by Princeton University Press, 41 William Street, Princeton, New Jersey 08540

In the United Kingdom: Princeton University Press, 3 Market Place, Woodstock, Oxfordshire OX20 1SY

All Rights Reserved

ISBN 0-691-08906-X (cloth : alk. paper)

Library of Congress Cataloging-in-Publication Data has been applied for

This book has been composed in Stone Serif and Stone Sans by Stephen I. Pargeter, Banbury, Oxfordshire, UK

Printed on acid-free paper. $\ominus$ www.pupress.princeton.edu

Printed in the United States of America

$\begin{array}{llllllllll}10 & 9 & 8 & 7 & 6 & 5 & 4 & 3 & 2 & 1\end{array}$ 
In loving memory of my father, Uzi 
